\title{
Effect of phytohormone and seed density toward growth, disease and bulb yield of True Shallot Seeds
}

\author{
Neni Gunaeni*, Rini Rosliani, Asih K. Karyadi, and Redy Gaswanto \\ Indonesia Vegetable Research Institute. Jl. Tangkuban Perahu No. 517 Lembang- Indonesia
}

\begin{abstract}
Shallot can be propagated generatively in the form True Seed of Shallot (TSS). The research purpose was to study phytohormone and sown seed density's effect on growth, disease, and bulbs yield. The research was conducted at Indonesian Vegetables Research Institute $(1,250 \mathrm{~m}$ asl), Lembang-West Java, from August 2017 until April 2018. The research used a factorial randomized completely block design with two factors repeated three times. The first factor was kind of phytohormone (A1 = BAP, A2 = NAA, A3 = GA3, A4 = control) and the second factor was the sown seed density $(B 1=5 \mathrm{~g} / \mathrm{m} 2, \mathrm{~B} 2=7 \mathrm{~g} / \mathrm{m} 2, \mathrm{~B} 3=9 \mathrm{~g} / \mathrm{m} 2)$. The result showed that: Phytohormone application did not affect germination and growth of TSS, living plant number, and bulb yield. The best-sown seed density to plant growth was $7 \mathrm{~g}$ seeds $/ \mathrm{m} 2$. Elisa's test result did not detect the viruses as seedborne diseases such as SYSV, OYDV, or LYSV. The intensity of disease symptoms Alternaria porri (11\%), Stemphylium vesicatorium, Colletotrichum gleosporiodes, and Peronospora destructor each (12\%). In general, the most bulb yield was informed single cloves.
\end{abstract}

\section{Introduction}

One of the main obstacles faced in efforts to increase shallot production at this time is the limited availability of quality shallot seeds. The shortage of quality seeds is met by using consumption bulbs as seeds or using imported bulbs. This will reduce the amount of consumption bulb production. The use of bulbs as seeds continuously by farmers can reduce the quality of the seeds due to the accumulation of bulb-borne pathogens, one of which is a viral disease which will reduce plant productivity. Therefore, technology is needed to produce shallot seeds as planting material or what is called true seed of shallot (TSS).

The results of [1] research have been able to produce shallot seeds through flowering by adding a long exposure time (TL lamp). According to [2], naturally shallots in Indonesia can produce TSS flowers and seeds, except for the Sumenep variety. The success of TSS seed production is influenced by the variety, bulb physiology, accuracy of cultivation, local climate, while vernalization (cooling the bulbs at $10^{\circ} \mathrm{C}$ for several weeks) and the application of ZPT (GA3) are the main keys of shallot flowering [2].

\footnotetext{
* Corresponding author: nenigunaeni@yahoo.com
} 
The advantage of TSS compared to using tuber seeds is that the yield of shallot bulbs up to two times (production 26 ton/ha), is free from disease and viruses, and the price of TSS seeds is 10 times cheaper than tubers, and has a longer shelf life [3]. Tuber seeds that are relatively easy to switch to TSS seeds need persistence in maintenance, especially at the beginning of growth [4]. Therefore, TSS seeds are used to produce mini bulbs $( \pm 3 \mathrm{~g}$ small bulb size) and then the mini bulbs are used as shallot seeds to produce consumption shallots.

Cultivation of shallots (Allium ascalonicum $\mathrm{L}$ ) through its botanical seeds or true shallot of seed (TSS) has advantages including: the volume of seeds used is much less, the need for bulb seeds is around $1.5 \mathrm{t} / \mathrm{ha}$, while seeds from TSS $7.5 \mathrm{~kg} / \mathrm{ha}$. Transportation costs are cheaper, storage is easier, plants derived from TSS are stronger and healthier because TSS seeds are virus free, and produce larger bulbs [5,6,7]. In addition, technically TSS technology can be said to be feasible because technology using traditional bulb seeds cannot increase yields by up to 2 times [8].

Production of bulbs from TSS seeds can be done through seeding TSS seeds first so that seedlings are produced, or direct planting of TSS seeds in the field (direct sowing) [9]. The constraints faced in producing TSS seeds are the presence of viral diseases that can be carried by the seeds, as well as low shallot flowering and seed formation. The results of research by [10] reported that the application of benzyl aminopurine (BAP) and boron could improve flowering rates and pollen viability which had implications for increasing the production and quality of TSS seeds in the highlands. The optimum BAP was obtained at a concentration of $37.5 \mathrm{ppm}$ which was applied by watering three times at the age of 1.3 and 5 weeks after planting. In the highlands, the bulb flowering period lasts for 25-30 days from the first umbel shoots to the last umbel shoots, the umbel stage appears and the harvest occurs 5-6 times [10].

The advantages of using TSS as a planting material are that the seeds are used less so that they are handled easier, are free from seed-borne diseases, and have a relatively longer shelf life than seed tubers $[11,12]$ and save more on production costs [8]. The success of flowering shallots in the highlands [13]. BAP of $50 \mathrm{ppm}$ given at one, three, and five weeks after planting (MST) could increase flowering and yield of shallot seeds in the highlands [10]. The objective research was to determine effect of the phytohormone and sown seed density to growth, diseases and bulb yield.

\section{Materials and methods}

The research is carried out in screenhouse and in the laboratory at the Indonesia Vegetable Research Institute in Lembang (plateau 1250 asl). Time of implementation from August 2017 to April 2018. Used is Factorial Randomized Completely Block Design with two factors that are repeated 3 times. The first factor (A) types of phytohormone consist of: A.1. BAP concentration of $50 \mathrm{ppm}$, A.2. NAA concentration of $50 \mathrm{ppm}$, A.3. GA3 concentration of 50 ppm, A.4. Control. The second factor is: (B). sown seeds density: B.1. sown seeds density 5 $\mathrm{g} / \mathrm{m}^{2}$, B.2. sown seeds density $7 \mathrm{~g} / \mathrm{m}^{2}$, B.3. sown seeds density $9 \mathrm{~g} / \mathrm{m}^{2}$.

There were 12 treatment combinations repeated three times. Using the Trisula shallot variety from TSS. TSS seeds according to treatment were weighed and packed in gauze bags, then soaked in each treatment of plant growth regulators for 1 hour, then drained overnight. Solarization was carried out on the nursery beds until the soil temperature reached $52^{\circ} \mathrm{C}$. The beds were made as high as $10 \mathrm{~cm}$ with a size of $1 \mathrm{~m} 2$ and the media was spread evenly (manure + husk charcoal + soil + dolomite) in a ratio of $1: 1: 1: 1$. The beds made of 10 rows, TSS seeds were sown according to the treatment evenly then covered with nursery media, watered and covered with burlap sacks to maintain moisture. Burlap sacks are opened when the seedlings have grown evenly. Mutiara NPK fertilizer (16:16:16) dose of $10 \mathrm{~g} / \mathrm{m} 2$ was 
given twice at the age of 30 and 60 days after sowing. Maintenance is carried out according to the state of the crop.

\subsection{Variables observed:}

1. Plant growth (plant height, number of leaves, and number of tillers). Observations were made 40 days after planting at one-week intervals. Plant height is measured from ground level to the highest shoots.

2. Number of living plants

3. Test of the Elisa

Elisa test using direct method. The antisera used were Onion Yellow Dwarf Virus (OYDV) and Shallot Yellow Stripe Virus (SYSV). Each plate hole was filled with $100 \mathrm{ul}$ of coating buffer solution containing IgG (Prime diagnostic, the Netherlands) with a concentration of $1: 1000(\mathrm{w} / \mathrm{v})$. Plates were incubated for 4 hours at $37^{\circ} \mathrm{C}$, then washed with $0.02 \mathrm{M}$ PBS-T three times. Each plate hole was filled with $100 \mathrm{ul}$ of antigen sample that had been crushed with $(0.02 \mathrm{M}$ PBS-T $+2 \%$ PVP $+0.2 \%$ ovalbumin) in a ratio of $1: 10(\mathrm{w} / \mathrm{v})$. Plates were incubated at $4{ }^{\circ} \mathrm{C}$ for one night. The plate the next day was washed six times with PBS-T. Each plate hole was filled with 100 ul of enzyme conjugate (Prime diagnostic, the Netherlands) dissolved in 0.02 PBS-T at a concentration of $1: 1000(\mathrm{v} / \mathrm{v})$, then incubated for 3 hours at $37^{\circ} \mathrm{C}$. The plate was washed with $0.02 \mathrm{M} \mathrm{PBS}$. -T six times. The plate holes were filled with $150 \mathrm{ul}$ of substrate buffer containing $1 \mathrm{mg} / \mathrm{ml}(\mathrm{w} / \mathrm{v}) \mathrm{PNP}$. Plates were incubated for 30 - 60 minutes at room temperature. The absorbance was measured using an Elisa Reader (Bio - Rad Model 550) at A $405 \mathrm{~nm}$.

4. Bulb yields (bulb weight and number of cloves).

\subsection{Data analysis}

Data were analyzed by Analysis of Variance (Anova).

\section{Results and discussion}

\subsection{Effect of Phytohormone and sown seeds density on shallot plant growth}

\subsubsection{Plant height growth}

The effect of treatment on plant height in the screenhouse (Figure 1) shows that the highest plant height is at treatment $7(\mathrm{GA} 3+5 \mathrm{~g} / \mathrm{m} 2)$ at the measurement of 84 DAS (days after planting), and the lowest is in treatment 11 (control $+7 \mathrm{~g} / \mathrm{m} 2$ ). According to Salisbury and Ross [14], giving the hormone gibberellin to plants that require stratification or light can induce germination and stimulate cell division and elongation. Most of the shallot plants in the screen house have small and yellowish leaves due to etiolation. The etiolated shallot plants affected seed immersion with GA3 [14]. The immersion of GA3 can also remove the coating of the seed wrapping that prevents water penetration into the embryo [15]. GA3 is a gibberellin hormone. meanwhile, for the treatment with seed volume of $7 \mathrm{~g} / \mathrm{m} 2$ and $9 \mathrm{~g} / \mathrm{m} 2$ with the same immersion treatment (GA3), the results were not significantly different. This can occur because the plants are too dense so that the plant height is less than the maximum compared to treatment $7(\mathrm{GA} 3+5 \mathrm{~g} / \mathrm{m} 2)$. Application of GA3 concentration affects plant growth and development [14]. The lower the number of plants or the wider the spacing, the 
better the plant growth will be. This is in accordance with the results of research, the denser the plant density, the slower the plant growth [16].

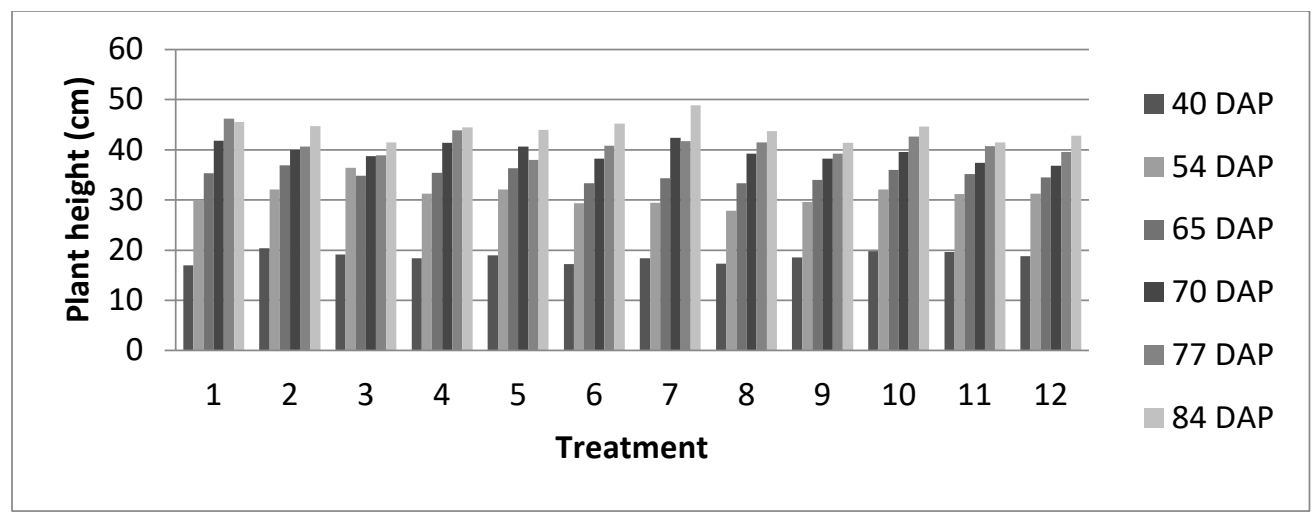

Fig. 1 Effect of phytohormone and sown seeds density on height plant of shallots in screenhouse

Description: (1). BAP + seeds $/ \mathrm{m}^{2}$ of $5 \mathrm{~g}$, (2). BAP + seeds $/ \mathrm{m}^{2}$ of $7 \mathrm{~g}$, (3). BAP + seeds $/ \mathrm{m}^{2}$ of $9 \mathrm{~g}$, (4). $\mathrm{NAA}+$ seeds $/ \mathrm{m}^{2}$ of $5 \mathrm{~g}$; (5). NAA + seeds $/ \mathrm{m}^{2}$ of $7 \mathrm{~g}$, (6). NAA + seeds $/ \mathrm{m}^{2}$ of $9 \mathrm{~g},(7)$. GA3 + seeds $/ \mathrm{m}^{2}$ of $5 \mathrm{~g},(8)$. GA3 + seeds $/ \mathrm{m}^{2}$ of $7 \mathrm{~g},(9)$. GA3 + seeds $/ \mathrm{m}^{2}$ of $9 \mathrm{~g},(10)$. Control + seeds $/ \mathrm{m}^{2}$ of $5 \mathrm{~g}$, (11). Control + seeds $/ \mathrm{m}^{2}$ of $7 \mathrm{~g}$, (12). Control $+\mathrm{seed} / \mathrm{m}^{2}$ of $9 \mathrm{~g}$.

\subsubsection{Number of tillers and leaves}

The effect of phytohormone and sown seeds density in the screenhouse had little effect on the number of tillers, the number of tillers was absent (single). This is not in accordance with the results of research $[17,18]$, the photosynthetic ability and the distribution of assimilate from the source sink to the plant can be increased with growth regulators for flower formation, seed and capsule development. The cause may be the inappropriate concentration of Phytohormone.

The phytohormone and sown seeds density on the number of shallot leaves in the screenhouse was not significantly different between plant growth regulator treatments and also controls at plant age $70-84$ day after planting (Figure 2). The effect of immersion of plant growth regulator did not give significantly different results, this is presumably because the timing of gift and the combination of treatments that are less precise affect the balance of growth regulators in plants. Provision of growth regulators depends on the concentration of phytohormone, plant parts, developmental phases, and environmental factors [19]. The number of shallot leaves is determined by genetic factors. [20]. 


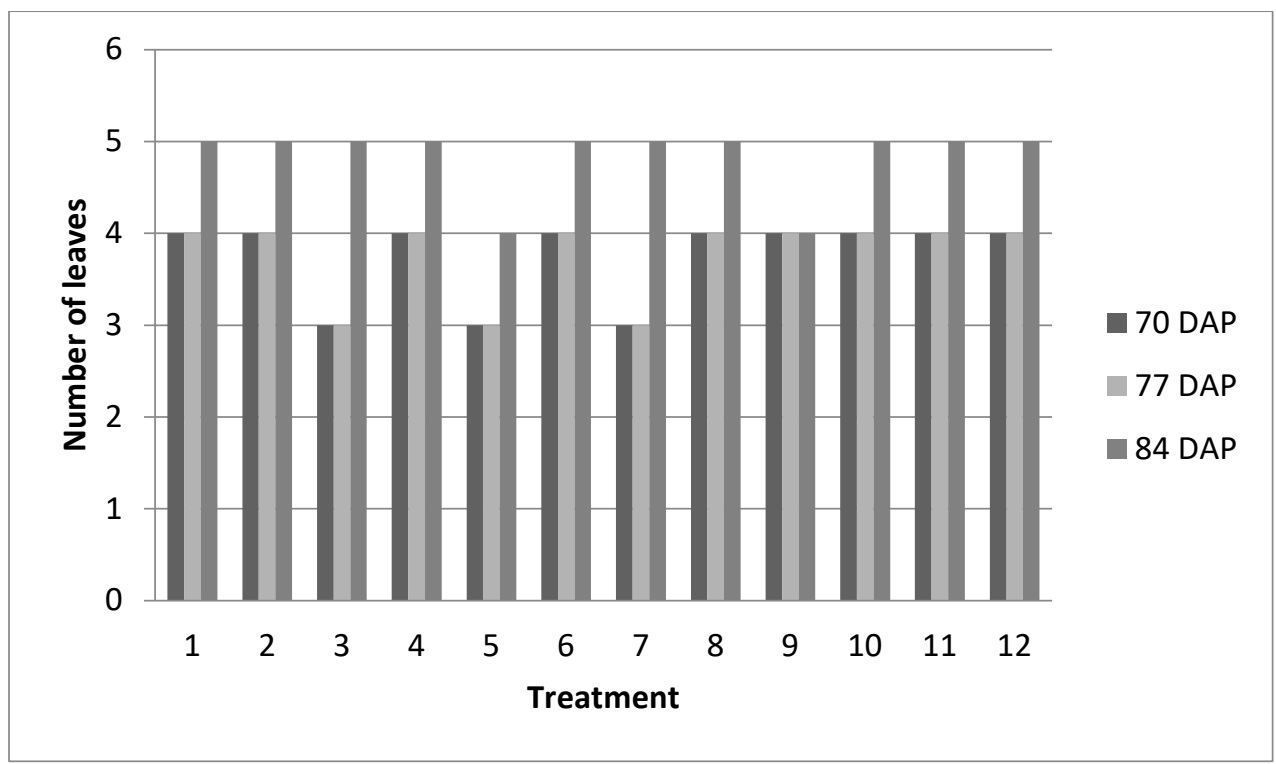

Fig. 2 Effect of phytohormone and sown seeds density on number of leaves of shallots in screenhouse

Description: (1). BAP + seeds $/ \mathrm{m}^{2}$ of $5 \mathrm{~g},(2) . \mathrm{BAP}+\operatorname{seeds} / \mathrm{m}^{2}$ of $7 \mathrm{~g},(3) . \mathrm{BAP}+9 \mathrm{~g}$ of seeds $/ \mathrm{m}^{2}$ of 9 $\mathrm{g}$, (4). NAA + seeds $/ \mathrm{m}^{2}$ of $5 \mathrm{~g}$; (5). NAA + seeds $/ \mathrm{m}^{2}$ of $7 \mathrm{~g},(6) . \mathrm{NAA}+$ seeds $/ \mathrm{m}^{2}$ of $9 \mathrm{~g}$, (7). GA3 + seeds $/ \mathrm{m}^{2} 5 \mathrm{~g}$, (8). GA3 + seeds $/ \mathrm{m}^{2}$ of $7 \mathrm{~g},(9)$. GA3 + seeds $/ \mathrm{m}^{2}$ of $9 \mathrm{~g},(10)$. Control + seeds $/ \mathrm{m}^{2}$ of $5 \mathrm{~g}$, (11). Control + seeds $/ \mathrm{m}^{2}$ of $7 \mathrm{~g}$, (12). Control $+\mathrm{seed} / \mathrm{m}^{2}$ of $9 \mathrm{~g}$.

\subsection{Number of living plants}

The number of live plants (Figure 3) was seen more in the treatment BAP+ seeds of $9 \mathrm{~g} / \mathrm{m}^{2}$, control + seeds of $7 \mathrm{~g} / \mathrm{m}^{2}$, control + seeds $9 \mathrm{~g} / \mathrm{m}^{2}$. Percentage of surviving plants from the number of seeds sown were $38.83 \%, 32.05 \%$, and $24.16 \%$, respectively. The number of live plants compared to the number of seeds sown was very low. This may be due in the screenhouse to the etiolation of the plant leaves, causing the plant leaves to fall down and turn yellow. Falling leaves caused plant leaves to a lack of sunlight. The shading of the leaves leads to an increase in the development of the disease. Such mutually shading leaves too tightly lead to increased disease progression. It seems that phytohormone have little effect on the number of living plants, the effect is the density of sown seeds of $7 \mathrm{~g}$ and $9 \mathrm{~g} \mathrm{per} \mathrm{m}^{2}$. This may be due to the inappropriate application of the phytohormone concentration. 


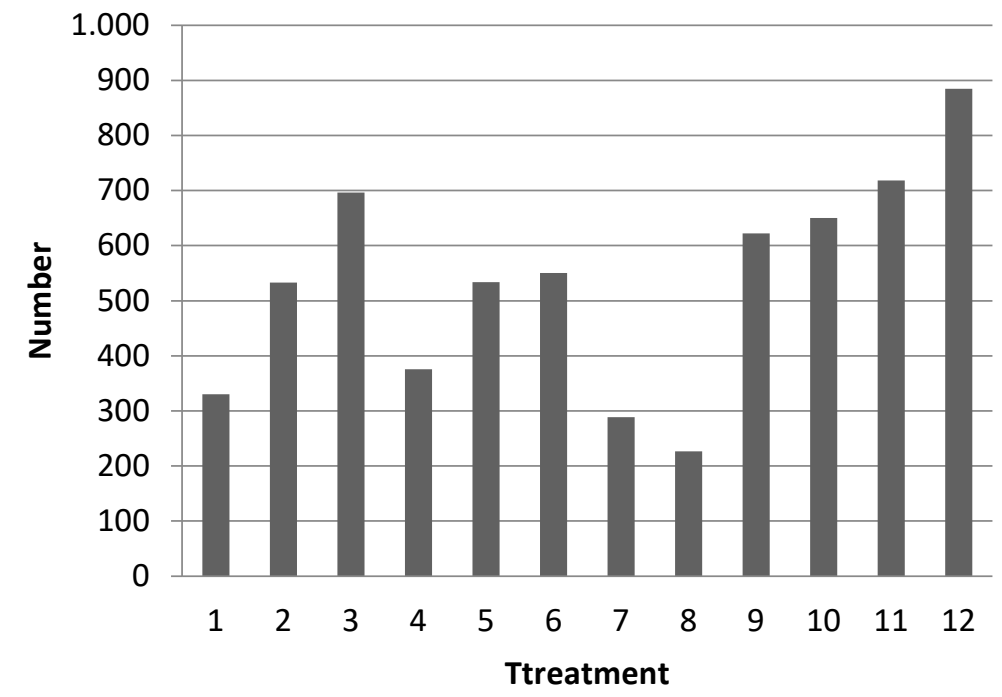

Living plant

Fig. 3 Effect of phytohormone and sown seeds density on the living plants of shallots in screenhouse

Description: (1). BAP + seeds $/ \mathrm{m}^{2}$ of $5 \mathrm{~g}$, (2). BAP + seeds $/ \mathrm{m}^{2}$ of $7 \mathrm{~g}$, (3). BAP + seeds $/ \mathrm{m}^{2}$ of $9 \mathrm{~g}$, (4). $\mathrm{NAA}+$ seeds $/ \mathrm{m}^{2}$ of $5 \mathrm{~g} ;(5)$. NAA + seeds $/ \mathrm{m}^{2}$ of $7 \mathrm{~g},(6) . \mathrm{NAA}+$ seeds $/ \mathrm{m}^{2}$ of $9 \mathrm{~g},(7)$. GA3 + seeds $/ \mathrm{m}^{2}$ $5 \mathrm{~g}$, (8). GA3 + seeds $/ \mathrm{m}^{2}$ of $7 \mathrm{~g}$, (9). GA3 + seeds $/ \mathrm{m}^{2}$ of $9 \mathrm{~g}$, (10). Control + seeds $/ \mathrm{m}^{2}$ of $5 \mathrm{~g}$, (11). Control + seeds $/ \mathrm{m}^{2}$ of $7 \mathrm{~g},(12)$. Control $+\mathrm{seed} / \mathrm{m}^{2}$ of $9 \mathrm{~g}$.

\subsection{The intensity of other diseases}

Observations of other diseases were carried out to see the presence of pathogens such as bacteria and fungi in shallot seeds and plants. Observations on sprouts were carried out by laboratory testing to see the morphology of the pathogen. The results of the observations can be seen in (Figure 4). From the experiments that have been carried out, there are diseases that attack shallot plants in screenhouse, including Alternaria, Anthracnose, Stemphylium and mildew diseases.

The purple blotch disease caused by Alternaria porri (Ell) Cif. The highest symptom of purple spot disease was NAA + seeds $/ \mathrm{m}^{2}$ of $5 \mathrm{~g} / \mathrm{m}^{2}(11 \%)$. Symptoms that arise on leaves that are attacked by Alternaria disease, namely, there are purple-gray spots in which a circular line looks like a ring. The spots enlarge to form hollows. This disease develops rapidly in onion plants, when the temperature reaches $21^{\circ} \mathrm{C}-30^{\circ} \mathrm{C}[21,22]$ its development is even more serious in humid and warm areas. This disease can reduce the yield by $57 \%$ and in quality causes the tubers to become small, often not even tubers are formed [23]. The morphology of Alternaria fungi has a brown or black conidium and is shaped like an inverted club with a size of $145 \mathrm{~mm}-370 \mathrm{~mm}$, has a longitudinal and transverse bulkhead, one end is enlarged and blunt, the other end is narrow and long. Conidium can be spread by wind and infect plants through stomata or wounds that occur in plants [24]. 


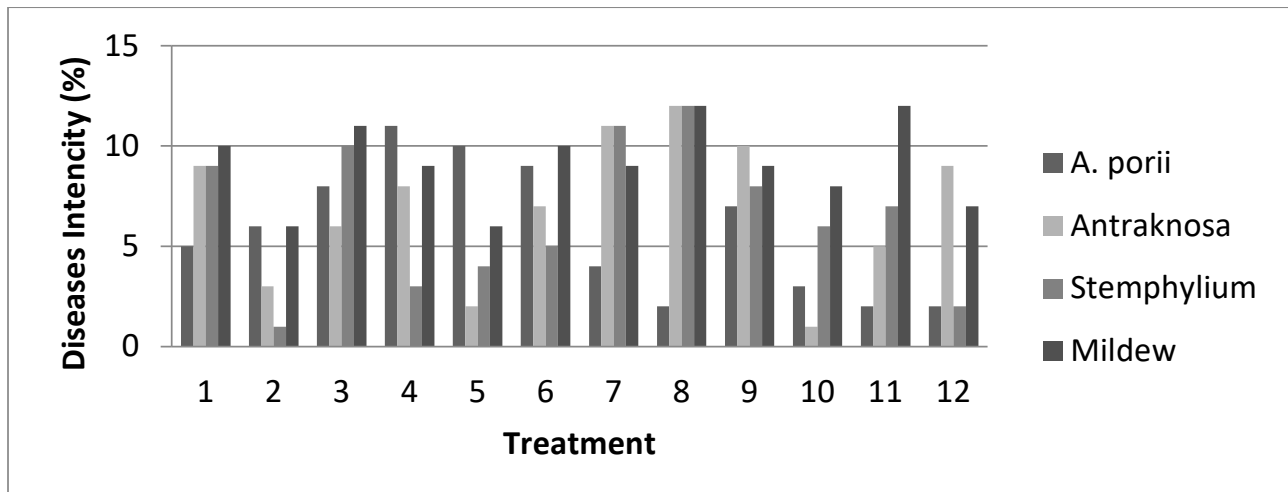

Fig. 4 Effect of phytohormone and sown seeds density on the disease's intensity of shallots in screenhouse

Description: (1). BAP + seeds $/ \mathrm{m}^{2}$ of $5 \mathrm{~g}$, (2). BAP + seeds $/ \mathrm{m}^{2}$ of $7 \mathrm{~g}$, (3). BAP $+9 \mathrm{~g}$ of seeds $/ \mathrm{m}^{2}$ of $9 \mathrm{~g}$, (4). NAA + seeds $/ \mathrm{m}^{2}$ of $5 \mathrm{~g}$; (5). NAA + seeds $/ \mathrm{m}^{2}$ of $7 \mathrm{~g}$, (6). NAA + seeds $/ \mathrm{m}^{2}$ of $9 \mathrm{~g}$, (7). GA3 + seeds $/ \mathrm{m}^{2} 5 \mathrm{~g}$, (8). GA3 + seeds $/ \mathrm{m}^{2}$ of $7 \mathrm{~g}$, (9). GA3 + seeds $/ \mathrm{m}^{2}$ of $9 \mathrm{~g},(10)$. Control + seeds $/ \mathrm{m}^{2}$ of $5 \mathrm{~g}$, (11). Control + seeds $/ \mathrm{m}^{2}$ of $7 \mathrm{~g}$, (12). Control $+\mathrm{seed} / \mathrm{m}^{2}$ of $9 \mathrm{~g}$.

Stemphylium disease is caused by the fungus Stemphylium vesicatory, anthracnose (Colletotrichum gleosporiodes) and powdery mildew (Peronospora destructor), symptoms of the disease were the highest GA3 + seeds $/ \mathrm{m}^{2}$ of $7 \mathrm{~g} / \mathrm{m}^{2}(12 \%)$. Symptoms of Stemphylium that occur in plants affected by this disease are yellowish white spots, grow very much and fast in accordance with the direction of the wind at the beginning of planting. The fungus is able to kill plants simultaneously. At high humidity, conidiophores and conidia will form very much on the leaf surface. The conidia are easily spread by the wind [25]. Symptoms of anthracnose are curved leaves, chlorosis, abnormal leaf neck length, few and short plant roots, small and thin tubers and rotten tubers. Symptoms of powdery mildew are fine purple hairs covering the outside of the leaves and stems.

\subsection{Test of elisa method}

Shallot samples for Elisa's test by the direct method were taken from the screen house at the age of 12 days after sowing. The results of the visual observation did not look yellow on the plate and based on the absorbance value the results of the Elisa instrument reading were under positive control. The sample is said to be positive if visually the Elisa test results on a yellow color plate and the absorbance value is 2 times the negative control. Elisa's reading results proved that the plant samples were not infected with the SYSV and OYDV viruses (Table 2). The use of TSS seeds has advantages over the use of seed tubers, which is to produce quality tubers because they come from healthy, disease-free plants [16, 26, 27, 5].

Viral disease is one of the obstacles in increasing the production of shallots. OYDV virus when combined with SYSV and SLV symptoms in plants gets worse. Symptoms of the virus are generally chlorosis, intermittent yellow stripes, leaves with green stripes and leaf size to be relatively smaller $[28,8,29]$. Symptoms in plants are less visible with increasing age of plants $[30,8]$. In Bima Curut and Philippine varieties, OYDV and SYSV infection could reduce the weight of shallot bulbs by $4.65 \%$ [29]. Testing with the Elisa method can detect and identify viruses in the vegetative phase [31,32], the samples tested can be in large quantities and the test material is in the form of plant extracts [33] 
Table 2. Elisa test results of OYDV and SYSV virus with the Indirect Elisa method

\begin{tabular}{|c|c|c|c|c|c|}
\hline \multirow{3}{*}{ No } & \multirow{3}{*}{ Sampel } & \multicolumn{4}{|c|}{ Antiserum } \\
\hline & & \multicolumn{2}{|c|}{ LYSV } & \multicolumn{2}{|c|}{ OYDV } \\
\hline & & Visual & Absorbance & Visual & Absorbance \\
\hline 1 & I.1 (BAP + 5 g) & - & 0.120 & - & 0.064 \\
\hline 2 & I.2 (BAP + $7 \mathrm{~g})$ & - & 0.081 & - & 0.044 \\
\hline 3 & I.3(BAP + 9 g) & - & 0.087 & - & 0.042 \\
\hline 4 & I.4 (NAA + 5 g) & - & 0.164 & - & 0.070 \\
\hline 5 & I.5 (NAA +7 g) & - & 0.129 & - & 0.064 \\
\hline 6 & I.6 (NAA + 9g) & - & -0.046 & - & 0.050 \\
\hline 7 & $\mathrm{I} .7(\mathrm{GA} 3+5 \mathrm{~g})$ & - & 0.101 & - & 0.063 \\
\hline 8 & I.8 (GA3 + $7 \mathrm{~g})$ & - & 0.064 & - & 0.027 \\
\hline 9 & I.9 (GA3 + 9 g) & - & 0.109 & - & 0.070 \\
\hline 10 & I.10 (Control + $5 \mathrm{~g})$ & - & 0.070 & - & 0.057 \\
\hline 11 & I.11 (Control + $7 \mathrm{~g}$ ) & - & 0.203 & - & 0.061 \\
\hline 12 & I.12 (Control + $9 \mathrm{~g})$ & - & 0.048 & - & 0.063 \\
\hline 13 & II.1 (BAP + 5 g) & - & 0.206 & - & 0.077 \\
\hline 14 & II.2 (BAP + $7 \mathrm{~g})$ & - & 0.205 & - & 0.086 \\
\hline 15 & II. $3(\mathrm{BAP}+9 \mathrm{~g})$ & - & 0.156 & - & 0.059 \\
\hline 16 & II.4 (NAA + $5 \mathrm{~g})$ & - & 0.162 & - & 0.047 \\
\hline 17 & II.5 (NAA + $7 \mathrm{~g})$ & - & 0.181 & - & 0.087 \\
\hline 18 & II.6 (NAA + 9 g) & - & 0.102 & - & 0.088 \\
\hline 19 & II.7 (GA3 + 5 g) & - & 0.217 & - & 0.074 \\
\hline 20 & II.8 (GA3 + $7 \mathrm{~g})$ & - & 0.162 & - & 0.057 \\
\hline 21 & II.9 (GA3 + 9 g) & - & 0.047 & - & 0.060 \\
\hline 22 & II.10 (Control $+5 \mathrm{~g})$ & - & 0.152 & - & 0.038 \\
\hline 23 & II.11 (Control + $7 \mathrm{~g}$ ) & - & 0.126 & - & 0.050 \\
\hline 24 & II.12 (Control + $9 \mathrm{~g})$ & - & 0.102 & - & 0.064 \\
\hline 25 & III.1 (BAP + 5 g) & - & 0.0065 & - & 0.050 \\
\hline 26 & III.2 (BAP + $7 \mathrm{~g})$ & - & 0.0035 & - & 0.022 \\
\hline 27 & III.3(BAP + 9 g) & - & 0.007 & - & 0.022 \\
\hline 28 & III.4 (NAA + 5 g) & - & 0.004 & - & 0.018 \\
\hline 29 & III.5 (NAA + 7 g) & - & 0.164 & - & 0.100 \\
\hline 30 & III.6 (NAA + 9 g) & - & 0.163 & - & 0.070 \\
\hline 31 & III.7 (GA3 + 5 g) & - & 0.153 & - & 0.081 \\
\hline 32 & III.8 $(\mathrm{GA} 3+7 \mathrm{~g})$ & - & 0.184 & - & 0.090 \\
\hline 33 & III.9 (GA3 + 9 g) & - & 0.046 & - & 0.064 \\
\hline 34 & III.10 (Control + 5 g) & - & 0.232 & - & 0.415 \\
\hline 35 & III.11 (Control + $7 \mathrm{~g})$ & - & 0.092 & - & 0.065 \\
\hline 36 & III.12 (Control + 9 g) & - & 0.218 & - & 0.061 \\
\hline 37 & Kontrol + & & 0.305 & & 0.119 \\
\hline 38 & Kontrol - & & 0.113 & & 0.070 \\
\hline
\end{tabular}

Description: - = negative; $+=$ positively infected with a virus

\subsection{Tuber yields (tuber weight and number of cloves)}

In Figure 5 the weight of wet and dry shallots as a result of various phytohormone treatments and the density of seeds sown showed the highest wet bulb weight in the treatment control + seed of $5 \mathrm{~g} / \mathrm{m} 2(2.52 \mathrm{~kg})$ with dry weight $(1.45 \mathrm{~kg})$ or decreased by $42.52 \%$. While the lowest GA3 + seeds were $7 \mathrm{~g} / \mathrm{m} 2(1.50 \mathrm{~kg})$ with dry weight $(0.83 \mathrm{~kg})$ or decreased by $44.69 \%$. The decrease in wet weight to dry weight in the screenhouse was between $35 \%-44.69 \%$. 
The number of cloves formed generally ranged from 1-2 (Graph 6). It can be seen that the highest number of cloves formed in a row was GA3 $+9 \mathrm{~g} / \mathrm{m} 2$ (667.33 cloves), GA3 $+5 \mathrm{~g} / \mathrm{m} 2$ (611.33 cloves) and NAA $+7 \mathrm{~g} / \mathrm{m} 2$ (583.33 cloves). compared to other treatments and controls. The highest number of cloves was seen in the BAP $+7 \mathrm{~g} / \mathrm{m} 2$ (4 cloves) treatment compared to other treatments and control.

The number of cloves formed generally ranged from 1-2 (Graph 6). It can be seen that the highest number of cloves formed in a row was GA3 $+9 \mathrm{~g} / \mathrm{m} 2$ (667.33 cloves), GA $3+5$ $\mathrm{g} / \mathrm{m} 2$ (611.33 cloves) and NAA $+7 \mathrm{~g} / \mathrm{m} 2$ (583.33 cloves). compared to other treatments and controls. The highest number of cloves was seen in the BAP $+7 \mathrm{~g} / \mathrm{m} 2$ (4 cloves) treatment compared to other treatments and control.

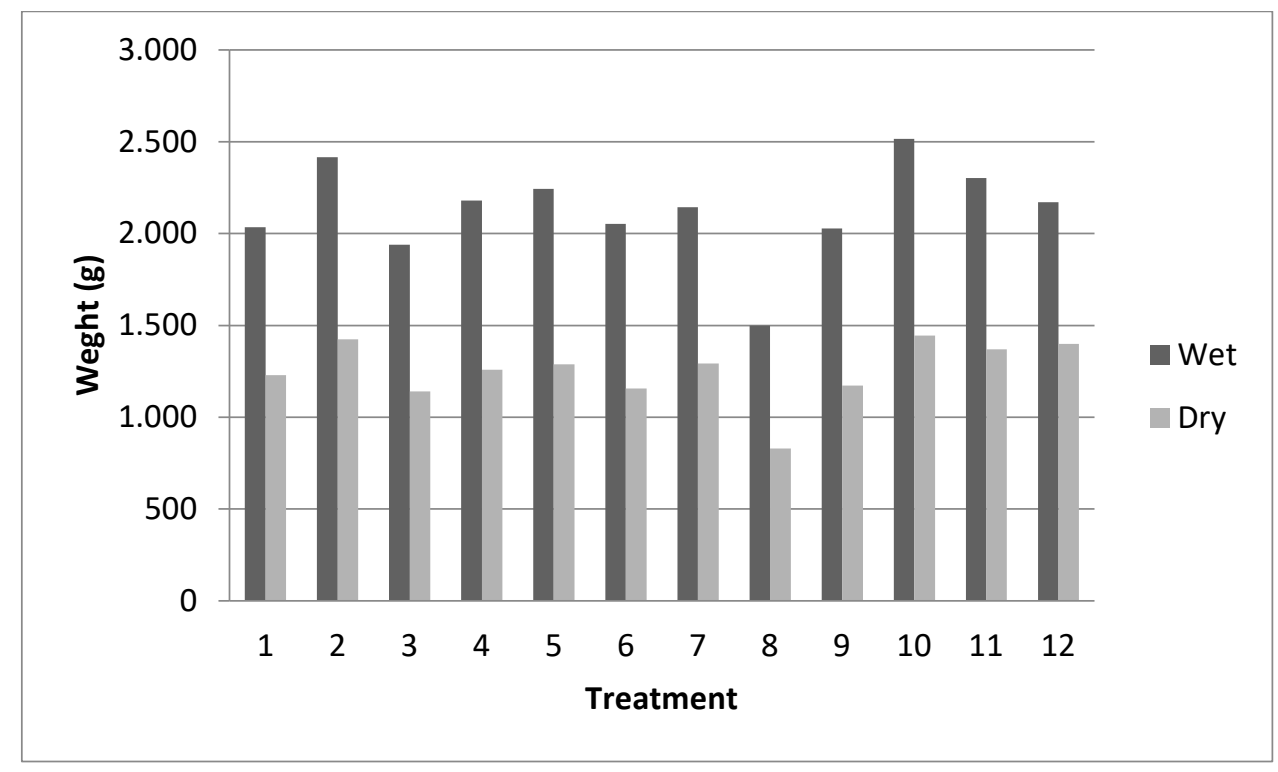

Fig. 5 Effect of phytohormone and sown seeds density on shallot bulb weight in screenhouse per $\mathrm{m}^{2}$

Description: (1). BAP + seeds $/ \mathrm{m}^{2}$ of $5 \mathrm{~g},(2)$. BAP + seeds $/ \mathrm{m}^{2}$ of $7 \mathrm{~g}$, (3). BAP $+9 \mathrm{~g}$ of seeds $/ \mathrm{m}^{2}$ of $9 \mathrm{~g}$, (4). NAA + seeds $/ \mathrm{m}^{2}$ of $5 \mathrm{~g}$; (5). NAA + seeds $/ \mathrm{m}^{2}$ of $7 \mathrm{~g},(6)$. NAA + seeds $/ \mathrm{m}^{2}$ of $9 \mathrm{~g}$, (7). GA3 + seeds $/ \mathrm{m}^{2} 5 \mathrm{~g},(8)$. GA3 + seeds $/ \mathrm{m}^{2}$ of $7 \mathrm{~g},(9)$. GA3 + seeds $/ \mathrm{m}^{2}$ of $9 \mathrm{~g},(10)$. Control + seeds $/ \mathrm{m}^{2}$ of 5 $\mathrm{g}$, (11). Control + seeds $/ \mathrm{m}^{2}$ of $7 \mathrm{~g},(12)$. Control $+\operatorname{seed} / \mathrm{m}^{2}$ of $9 \mathrm{~g}$. 


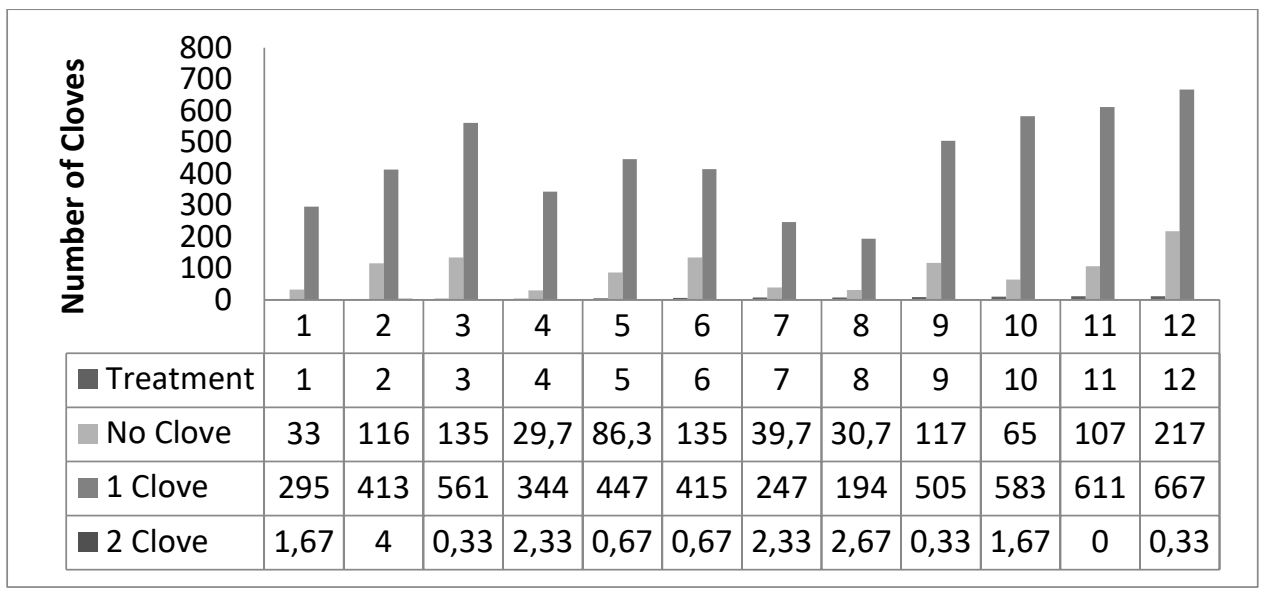

Fig. 6 Effect of phytohormone and sown seeds density on number of cloves on shallots in the screenhouse per $\mathrm{m}^{2}$

Description: (1). BAP + seeds $/ \mathrm{m}^{2}$ of $5 \mathrm{~g}$, (2). BAP + seeds $/ \mathrm{m}^{2}$ of $7 \mathrm{~g}$, (3). BAP $+9 \mathrm{~g}$ of seeds $/ \mathrm{m}^{2}$ of $9 \mathrm{~g}$, (4). NAA + seeds $/ \mathrm{m}^{2}$ of $5 \mathrm{~g}$; (5). NAA + seeds $/ \mathrm{m}^{2}$ of $7 \mathrm{~g},(6)$. NAA + seeds $/ \mathrm{m}^{2}$ of $9 \mathrm{~g}$, (7). GA3 + seeds $/ \mathrm{m}^{2} 5 \mathrm{~g},(8) . \mathrm{GA} 3+$ seeds $/ \mathrm{m}^{2}$ of $7 \mathrm{~g}$, (9). GA $3+$ seeds $/ \mathrm{m}^{2}$ of $9 \mathrm{~g},(10)$. Control + seeds $/ \mathrm{m}^{2}$ of 5 $\mathrm{g}$, (11). Control + seeds $/ \mathrm{m}^{2}$ of $7 \mathrm{~g},(12)$. Control $+\mathrm{seed} / \mathrm{m}^{2}$ of $9 \mathrm{~g}$.

\subsection{Implementation of bulb seed production of TSS}

One of supported factor to create self-sufficient of shallot successfully is supply of good seed quality. For this time, farmers used shallot seed in form vegetative bulbs. Nevertheless, there are some lacks of vegetative bulbs, so that sometimes causing insufficient seeds especially while off season. The botanic seed which known as true seed of shallot (TSS) can be used as an alternative approach to fulfill seed supply.

Based on the research results showed that there was no interaction between kind of phytohormones with sown seed density. Furthermore, phytohormone application was less affect significantly to germination, growth, living plant number, and bulbs yield of TSS. Possibility it caused by only one applicated dose to three kinds of phytohormones, in this case $50 \mathrm{ppm}$, therefore the condition was less variation to find out a differentiation. For this reason, it is necessary to study the appropriate dose of phytohormone to be applied. Another possibility is the application of doses and phytohormone is more properly for setting up flowering than bulbs formation of TSS.

The research results also showed that the best of sown seed density treatment was $7 \mathrm{~g}$ seeds $/ \mathrm{m}^{2}$. This is an important information for using TSS efficiently to be order to obtain standard bulbs as a vegetative seed. Nevertheless, in general the most bulb yield was in form as single clove. This condition is not advantage for seed producers because only less quantity propagation. It is needed a precise cultivation technique for solving this problem, so that the produced bulbs of TSS is more than one clove. Another solution that can be implemented is replanting the produced bulbs to increase clove quantity number per bulb.

One obstacle of bulb-to-bulb seed propagation is degeneration quality caused by seed borne disease. However, TSS has an advantage as a shallot seed alternative, in this case the produced bulb is healthy and clean of seed borne pathogens, therefore good for shallot seed propagation. It was proved by the Elisa test result on the produced bulbs of TSS. It was not detected kinds of viruses, known as seed borne disease, such as SYSV, OYDV, and LYSV. Finally, the research result in some part can be implemented for farmers or seed producers, while in another part still has to be studied anymore. 


\section{Conclusion}

Phytohormone application did not affect to germination and growth of TSS, living plant number, and bulb yield. The best sown seed density to plant growth was $7 \mathrm{~g}$ seeds $/ \mathrm{m}^{2}$. Elisa test result was not detected the kinds of viruses as known as seed borne disease such as SYSV, OYDV, and LYSV. Intensity of disease symptoms Alternaria porri (11\%), Stemphylium vesicatorium, Colletotrichum gleosporiodes and Peronospora destructor each (12\%). In general, the most bulb yield was in form single cloves. The research result in some part can be implemented for farmers or seed producers, while in another part still has to be studied anymore

Acknowledgements. Main author is thankful and appreciation goes to Dr. Redy Gaswanto, SP, MP has given advise and correction.

\section{References}

1. I.R. Moeljani, Environmental Engineering to Increase Flowering and Fertility Production of TSS (True Seed of Shallot) Shallots (Allium sativum L). Dissertation]. Surabaya [ID]. Airlangga University. 2015.

2. Suwandi, Shallot Seed Technology through TSS (True Seed of Shalot) Agricultural Research and Development Agency. (Assessed at 2021 May 4). http://www.hortikultura.litbang.pertanian.go.id.

3. Agricultural Research and Development. Scarcity of shallots, the solution is in onion seeds. Downloaded 2021 February 20]. http://www.litbang.pertanian.go.id/berita/o ne / 2091/.

4. Prayudi B, Pangestuti R, Kusumasari AC. 2015. Production of Mini Shallot Bulbs from True Seed of Shallot (TSS). In: Hortikutura Innovations Leveraging People's Income Increase. Jakarta (ID): IAARD Press.

5. N. Sumarni, G.A. Sopha, R. Gaswanto. J. Hort. 22. (2012)

6. G.A. Sopha, N. Sumarni, W. Setiawati, S. Suwandi. J. Hort. 25. (2016)

7. G.A. Sopha, M. Syakir, S. Wiwin, S. Suwandi, Sumarni. 2017. J Hort. 27. (2017)

8. R.S. Basuki. J Hort. 19. (2009)

9. N. Sumarni, R. Rosliani. J. Hort. 12. (2002)

10. R. Rosliani, E.R. Palupi, Y. Hilman. J. Hort. 22. (2012)

11. S. Putrasamedja. J. Hort. 5,1, (1995)

12. N. Sumarni, E. Sumiati, Suwandi. J. Hort.15. (2005)

13. S. Putrasamedja, A.H. Permadi. Bul. Penel. Hort. 26. (1994)

14. F.B. Salisbury, C.W. Ross. Plant Physiology volume III. (Bandung Institute of Technology, Bandung, Indonesia, 1995)

15. L.O. Copeland. Seed Germination. Principles of Seed Science and Technology. (Department of Crop and Soil Sciences Michigan State University, Burgess Publishing Co. Minneapolis, Minnesota, USA, 1976)

16. W. Handayati, Study of plant growth performance and flower quality of new high yielding chrysanthemum cut flower varieties at two types of plant density. National Seminar on Food and Energy Sovereignty, Faculty of Agriculture, Trunojoyo Madura University, June 2012.

17. M.M. Amanullah, S. Sekar, S. Vincent. Asian J. Plant Sci. 9. (2010)

18. R. Rosliani, E.R. Palupi, Y. Hilman. J. Hort. 23. (2013)

19. M. Ibrahim, A. Nuraini, D. Widayat., D. Cultivation J. 14. (2015)

20. N. Sumarni, Suwandi, N. Gunaeni, S. Putrasamedja, Hort. 23. (2013)

21. R.L. Skiles. Phytopathol. 43. (1953) 
22. R.P. Soedomo. J. Hort. 16. (2006)

23. S. Nur. J. Agric. Sci. 1. (2016)

24. Directorate of Horticultural Protection, 2006. Becak Ungu or Trotol (Purple Blotch) Alternaria porri. $\quad<$ http://www.deptan.go.id/ditlinhorti/opt/bemerah/trotol.htm> Accessed on 20 January 2018.

25. B.K. Udiarto, W. Setiawati, E. Suryaningsih. Introduction to Pests and Diseases in Shallot Plants and Their Control. (Vegetable Crops Research Institute. LembangBandung, Indonesia, 2005)

26. A.H. Permadi, Growing shallot from true seed. Research results and problems. Onion Newsletter for the Tropics, 5, 5, (2003)

27. J.P. Sumanaratne, W.M.U. Palipane, S. Kumary. Annal of the Sri Langka Department of Agriculture. 4, (2005)

28. H. Fidan, S. Baloglu. Plant Disease, 93, 6, (2009)

29. A.W. Wulandari, S.H. Hidayat, S. Sobir. Hort. J. 25, 4, (2016)

30. B. Yanju, W. Zhang, L. Xuezhan, S. Yanling, F. Guoquan, G. Hongwei, B. Xianxin. J. Northeast Agric. University. 17, 2, (2010)

31. S. Seal, J. Elphinstone. Advances in identification and detection of P. solanacearum. In The Disease and Its Causative Agent, P. solanacearum. CAB International, Wallingford, UK, 1994)

32. R.H. Converse, R.R Martin. ELISA methods for plant viruses. In Serological Methods for Detection and Identification of Viral and bacterial Plant Patogens. APS Press, St Paul, Minn. 1990)

33. Y. Suryadi, I. Manzila, M. Machmud. J. Agro Biogen. 5, 1, (2009) 